\title{
Hubungan Pendidikan dan Pengetahuan Pemberian Susu Formula terhadap Kejadian Diare pada Anak Usia 0 - 2 Tahun
}

\author{
${ }^{1}$ E. Yuniarti*, ${ }^{2}$ N. N. Vinnata \\ ${ }^{1,2}$ Fakultas Ilmu Kesehatan, Universitas Katolik Musi Charitas \\ Email : eviyuniarti@ukmc.ac.id
}

\section{Kata kunci : \\ Pendidikan, \\ Pengetahuan, \\ Diare. \\ Keywords : \\ Education, \\ Knowledge, \\ Diarrhea}

\section{Info Artikel:}

Tanggal dikirim:

12 Maret 2020

Tanggal direvisi:

16 Mei 2020

Tanggal diterima :

04 Juni 2020

DOI Artikel: 10.33862/citradelima. v4i1.96

Halaman: 7 - 11

\begin{abstract}
Abstrak
Susu formula merupakan media yang baik bagi pertumbuhan bakteri, sehingga kontaminasi mudah terjadi terutama jika persiapan dan pemberian kurang memperhatikan segi antiseptik. Pemberian susu formula yang tidak baik dapat meningkatkan risiko terjadinya diare pada bayi. Jenis penelitian ini adalah kuantitatif dengan menggunakan metode survei analitik dengan pendekatan cross sectional. Pengambilan sampel dalam penelitian ini dilakukan dengan metode non random (non Probability) sampling dengan menggunakan tekhnik accidental sampling yaitu pengambilan sampel secara accidental ini dilakukan dengan mengambil kasus atau responden yang kebetulan ada atau tersedia di suatu tempat sesuai dengan konteks penelitian yaitu sebanyak 64 responden. Hasil analisis responden dengan pendidikan tinggi ada $25,49 \%$ yang bayinya diare, sedangkan pendidikan rendah ada $69,23 \%$ yang bayinya mengalami diare, didapatkan $p$ value $=0,007$ lebih kecil dari $\alpha=0,05$ menunjukkan bahwa ada hubungan bermakna antara pendidikan ibu dengan kejadian diare. responden yang mengetahui cara pemberian susu formula ada $7,14 \%$ yang bayinya mengalami diare. sedangkan responden yang tidak mengetahui cara pemberian susu formula ada $83,63 \%$ yang bayinya mengalami diare. Hasil analisis didapatkan $p$ value $=0,000$ lebih kecil dari $\alpha=0,05$ menunjukkan bahwa ada hubungan bermakna antara pengetahuan ibu dengan kejadian diare. Responden yang tidak menggunakan susu formula yang mengalami diare yaitu $0 \%$. Yang menggunakan susu formula yang mengalami diare yaitu 42,30\%. Hasil analisis didapatkan $p$ value $=0,005$ lebih kecil dari $\alpha=0,05$ menunjukkan bahwa ada hubungan bermakna antara pemberian susu formula terhadap kejadian diare. Diharapkan Puskesmas dapat membuat program yang inovatif sebagai upaya yang dapat dilakukan untuk mencegah terjadinya diare.
\end{abstract}

\section{Relationship of Education and Knowledge of Formula Milk Feeding for Diarrhea in children aged 0-2 years}

\begin{abstract}
Formula milk is a good medium for bacterial growth, so contamination is easy, especially if the preparation and administration pay less attention to antiseptic aspects. Poor formula feeding can increase the risk of diarrhea in infants. This type of research is quantitative using analytic survey methods with cross sectional approach. Sampling in this study was carried out by the method of non-random (non-probability) sampling using accidental sampling technique that is accidental sampling is done by taking cases or respondents who happen to be there or available in a place in accordance with the context of the study as many as 64 respondents. The results of the analysis of respondents with higher education there were $25.49 \%$ of babies whose diarrhea, while low education there were $69.23 \%$ whose babies had diarrhea, $\mathrm{p}$ value $=0.007$ was smaller than $\alpha=0.05$, indicating that there was a significant relationship between mother's education and diarrhea occurrences. there were $7.14 \%$ of respondents who knew how to give formula milk whose babies had diarrhea. while respondents who did not know how to give formula milk there were $83.63 \%$ whose babies had diarrhea. The results of the analysis showed that $p$ value $=0,000$ is smaller than $\alpha=0.05$, indicating that there is a significant relationship between maternal knowledge and the incidence of diarrhea. Respondents who did not use formula milk with diarrhea were $0 \%$. Those who use formula milk who have diarrhea are $42.30 \%$. The analysis results obtained $\mathrm{p}$ value $=0.005$ smaller than $\alpha=0.05$ indicating that there is a significant relationship between formula feeding and the incidence of diarrhea. It is hoped that the Puskesmas can create innovative programs as an effort to prevent diarrhea.
\end{abstract}

http://jurnalilmiah.stikescitradelima.ac.id/index.php/JI Vol.4,No.1, Juli 2020 


\section{PENDAHULUAN}

Diare adalah pengeluaran tinja yang tidak normal dan cair. Buangan air besar yang tidak normal dan bentuk tinja yang cair dengan frekuensi yang lebih banyak dari $3 \mathrm{x}$ buang air besar, sedangkan pada neonates dikatakan diare apabila lebih dari 4x buang air besar (Dwinda $\mathrm{R}$, Octa, dkk, 2014).

Diare dapat disebabkan oleh berbagai infeksi, selain penyebab lain seperti malabsorbsi. Diare sebenarnya merupakan salah satu gejala dari penyakit pada sistem gastrointestinal atau penyakit lain di luar saluran pencernaan. Tetapi sekarang dikenal dengan penyakit diare karena sebutan penyakit diare akan mempercepat tindakan penanggulangannya. Penyakit diare terutama pada bayi perlu mendapatkan tindakan secepatnya karena dapat membawa bencana bila penangananannya terlambat (Ngastiyah, 2012).

Diare sering dijumpai di masyarakat terutama oleh makanan dan minuman yang terkontaminasi akibat akses kebersihan yang buruk. Faktor ibu berperan sangat penting dalam kejadian diare pada balita. Ibu adalah sosok yang paling dekat dengan balita. Jika balita terserang diare maka tindakan-tindakan yang ibu ambil akan menentukan perjalanan penyakitnya. Tindakan tersebut dipengaruhi berbagai hal, antara lain adalah tingkat pendidikan, pengetahuan dan tindakan pencegahan terhadap diare (Bintoro,2010 dalam Dewiarti,2013).

Menurut Sutomo di dalam Kalay (2012), susu formula adalah susu buatan pabrik yang telah diformulasikan menyerupai ASI, walaupun ASI tetap yang terbaik untuk balita. Penyebab terjadinya diare sangat identik disebabkan oleh makanan dan minuman yang tidak bersih, basi, beracun, atau alergi terhadap makanan. Selain itu diare juga dapat disebabkan adanya gangguan penyerapan makanan, seperti karbohidrat (intoleransi laktosa), lemak, dan protein.

World Health Organization (WHO) dan United Nations Children's Fund (UNICEF) menyatakan anak yang menderita diare berusia di bawah 5 tahun terutama di negara berkembang sebanyak 1,9 juta dan merupakan salah satu penyebab kematian bayi dan balita terbesar di dunia. Kesehatan anak masih sangat rentan pada usianya di dua tahun pertama merupakan usia paling rentan terjangkit diare dengan usia terbanyak rata rata 6-11 bulan (Prihaningtyas,2014)

Secara global setiap tahunnya ada sekitar 2 miliar kasus diare dengan angka kematian 1.5 juta pertahun. Pada negara berkembang, anak-anak usia dibawah 3 tahun rata-rata mengalami 3 episode diare pertahun. Setiap episodenya diare akan menyebabkan kehilangan nutrisi yang dibutuhkan anak untuk tumbuh, sehingga diare merupakan penyebab utama malnutrisi pada anak (WHO, 2011).

Berdasarkan data dari Profil Kesehatan Indonesia pada tahun 2016 kejadian diare yang ditangani sebesar 36,9 \%, sedangkan pada tahun 2017 cakupan pelayanan penderita diare pada balita 40,07\%, jumlah ini mengalami peningkatan sedikit pada tahun 2018 dimana cakupan pelayanan penderita diare pada balita sebesar $40,90 \%$.

Berdasarkan profil kesehatan kota Palembang tahun 2017, penderita diare pada tahun 2015 adalah 38.721 jiwa dengan cakupan 114,48\%, tahun 2016 adalah 37.896 jiwa dengan angka cakupan 110,53\%, dan pada tahun 2017 penderita diare 41.957 jiwa dengan cakupan $97 \%$.

Data yang didapatkan dari Puskesmas "B" Palembang, kejadian diare pada balita tahun 2018 adalah 521 kasus pada tahun 2017 adalah 611 kasus.

Berdasarkan data-data diatas, maka penulis ingin melakukan penelitian tentang " Hubungan Pendidikan dan Pengetahuan Pemberian Susu Formula Terhadap Kejadian Diare di Puskesmas "B" Kota Palembang Tahun 2019”.

http://jurnalilmiah.stikescitradelima.ac.id/index.php/JI Vol.4,No.1, Juli 2020 


\section{METODE}

Metode penelitian ini menggunakan metode survei analitik dengan pendekatan cross sectional. Pengambilan sampel dalam penelitian ini dilakuka dengan metode non random (non Probability) sampling dengan menggunakan tekhnik accidental sampling yaitu pengambilan sampel secara accidental ini dilakukan dengan mengambil kasus atau responden yang kebetulan ada atau tersedia di suatu tempat sesuai dengan konteks penelitian yaitu sebanyak 64 responden.

Pada penelitian ini analisa univariat dilakukan utuk mendapatkan distribusi frekuensi variabel (diare, pendidikan, pengetahuan dan pemberian susu formula).

Analisis bivariat menggunakan uji Chi Square dengan tingkat kesalahan terbesar (level significancy) 0,05 atau 5\% dan tingkat kepercayaan (confidence level) $95 \%$. Dengan ketentuan apabila nilai $\mathrm{p}>\mathrm{a}(\mathrm{p}>0.05)$, maka keputusannya $\mathrm{Ho}=$ diterima, berarti tidak ada hubungan yang bermakna. Dalam melakukan uji statistik ini dengan menggunakan analisis regresi logistik sederhana dengan tingkat kemaknaan (nilai p) sebesar 0,05 artinya apabila $\mathrm{p}$ value $>0,05$ berarti secara signifikasi analisis ini untuk melihat faktor mana yang dominan kemaknaan hubungan dilihat pada $\mathrm{p}>0,05$ dan CI $95 \%$.

\section{HASIL DAN PEMBAHASAN}

\section{Pendidikan Ibu dengan Kejadian Diare}

Tabel 1. Hubungan antara pendidikan ibu dengan kejadian diare.

\begin{tabular}{|c|c|c|c|c|c|c|c|}
\hline \multirow{3}{*}{$\begin{array}{c}\text { Pendidi } \\
\text { kan }\end{array}$} & \multicolumn{4}{|c|}{ Diare } & \multirow{2}{*}{\multicolumn{2}{|c|}{ Jumlah }} & \multirow{3}{*}{$\begin{array}{c}P \text { - } \\
\text { Value }\end{array}$} \\
\hline & \multicolumn{2}{|c|}{ Tidak (f \%) } & \multicolumn{2}{|c|}{ Ya (f \%) } & & & \\
\hline & $n$ & $\%$ & $\mathbf{n}$ & $\%$ & $\mathbf{N}$ & $\%$ & \\
\hline Tinggi & 38 & $\begin{array}{c}74,5 \\
0\end{array}$ & 13 & $\begin{array}{c}25,4 \\
9\end{array}$ & 51 & 100 & 0,007 \\
\hline Rendah & 4 & $\begin{array}{c}30,7 \\
7\end{array}$ & 9 & $\begin{array}{c}69,2 \\
3\end{array}$ & 13 & 100 & \\
\hline Total & 42 & $\begin{array}{c}65,6 \\
2\end{array}$ & 22 & $\begin{array}{c}34,3 \\
7\end{array}$ & 64 & 100 & \\
\hline
\end{tabular}

64 orang sampel responden dengan pendidikan tinggi ada $25,49 \%$ yang bayinya diare, sedangkan pendidikan rendah ada $69,23 \%$ yang bayinya mengalami diare. Hasil analisis didapatkan $\mathrm{p}$ value $=0,007$ lebih kecil dari $\alpha=$ 0,05 menunjukkan bahwa ada hubungan bermakna antara pendidikan ibu. dengan kejadian diare pada bayi usia 0-2 tahun di puskesmas "B".

Sesuai dengan teori (Bintoro 2010 dalam Dewiarti,2013) Diare sering dijumpai di masyarakat terutama oleh makanan dan minuman yang terkontaminasi akibat akses kebersihan yang buruk. Faktor ibu berperan sangat penting dalam kejadian diare pada balita. Ibu adalah sosok yang paling dekat dengan balita. Jika balita terserang diare maka tindakan-tindakan yang ibu ambil akan menentukan perjalanan penyakitnya. Tindakan tersebut dipengaruhi berbagai hal, antara lain adalah tingkat pendidikan, pengetahuan dan tindakan pencegahan terhadap diare.

Hal ini sejalan dengan penelitian yang dilakukan oleh fathia, dkk. 2015, yang berjudul Hubungan Tingkat Pendidikan dan Pengetahuan Ibu tentang Diare dengan Frekuensi Kejadian Diare Balita di Wilayah Kerja Puskesmas Tamansari yang mengatakan bahwa terdapat hubungan yang signifikan antara tingkat pendidikan ibu dan frekuensi kejadian diare ( $\mathrm{p}$ value $=0,007$ ).

Berdasarkan hasil penelitian dan teori yang ada, peneliti berpendapat bahwa ada hubungan antara pendidikan ibu dengan kejadian diare dimana semakin rendah pendidikan ibu maka semakin tinggi kejadian diare pada balita.

\section{Pengetahuan Ibu dengan Kejadian Diare}

Tabel 2. Hubungan antara pengetahuan ibu dengan kejadian diare.

\begin{tabular}{|c|c|c|c|c|c|c|c|}
\hline \multirow{3}{*}{$\begin{array}{c}\text { Pengetah } \\
\text { uan }\end{array}$} & \multicolumn{4}{|c|}{ Diare } & \multirow{2}{*}{\multicolumn{2}{|c|}{ Jumlah }} & \multirow{3}{*}{$\begin{array}{c}P- \\
\text { Value }\end{array}$} \\
\hline & \multicolumn{2}{|c|}{ Tidak (f \%) } & \multicolumn{2}{|c|}{ Ya (f \%) } & & & \\
\hline & $n$ & $\%$ & $\mathbf{n}$ & $\%$ & $\mathbf{N}$ & $\%$ & \\
\hline $\begin{array}{c}\text { Mengetah } \\
\text { ui }\end{array}$ & 39 & $\begin{array}{c}92,8 \\
6\end{array}$ & 3 & 7,14 & 42 & 100 & 0,000 \\
\hline Tidak & 3 & 13,6 & 19 & 86,3 & 22 & 100 & \\
\hline $\begin{array}{c}\text { Mengetah } \\
\text { ui }\end{array}$ & & 3 & & 6 & & & \\
\hline Total & 42 & $\begin{array}{c}65,6 \\
2\end{array}$ & 22 & $\begin{array}{c}34,3 \\
7\end{array}$ & 64 & 100 & \\
\hline
\end{tabular}

http://jurnalilmiah.stikescitradelima.ac.id/index.php/JI Vol.4,No.1, Juli 2020 
Dari hasil analisis dapat disimpulkan bahwa dari 64 orang sampel, responden yang mengetahui cara pemberian susu formula ada $7,14 \%$ yang bayinya mengalami diare. sedangkan responden yang tidak mengetahui cara pemberian susu formula ada $83,63 \%$ yang bayinya mengalami diare. Hasil analisis didapatkan $\mathrm{p}$ value $=0,000$ lebih kecil dari $\alpha=0,05$ menunjukkan bahwa ada hubungan bermakna antara pengetahuan ibu dengan kejadian diare pada bayi usia 0-2 tahun di puskesmas " $\mathrm{B}$ ".

Adanya kejadian diare pada balita dapat disebabkan karena kesalahan pemberian makanan. Kesalahan ini dapat berupa bayi yang diberi makanan selain ASI pada usianya yang baru 4 bulan atau adanya praktek pemberian makan bayi dengan susu formula atau replacement feeding (WHO, 2009).

Hal ini didukung oleh penelitian dari Sriwahyuni dan Soedirham (2014), bahwa terdapat hubungan antara pengetahuan dengan penyakit diare pada balita ( $p$ value $=0,039)$.

Berdasarkan hasil penelitian dan teori yang ada, peneliti berpendapat bahwa ada hubungan antara pengetahuan ibu dengan kejadian diare pada bayi usia 02 tahun di puskesmas "B". Dimana apabila ibu mengetahui cara pemberian susu formula yang benar maka kejadian diare semakin rendah.

\section{Hubungan Pemberian Susu Formula dengan Kejadian Diare}

Tabel 3. Hubungan antara pemberian susu formula dengan kejadian diare.

\begin{tabular}{cccccccc}
\hline \multirow{2}{*}{$\begin{array}{c}\text { Susu } \\
\text { Formula }\end{array}$} & \multicolumn{5}{c}{ Diare } & Tidak (f \%) & \multicolumn{2}{c}{ Ya (f \%) } & Jumlah & \begin{tabular}{c}
$\boldsymbol{P}$ - \\
\cline { 2 - 6 }
\end{tabular} & $\mathbf{n}$ & $\%$ & $\mathbf{n}$ & $\%$ & $\mathbf{N}$ & $\%$ & Value \\
\hline $\begin{array}{c}\text { Mengguaka } \\
\text { n susu } \\
\text { formula }\end{array}$ & 12 & 100 & 0 & 0 & 12 & 100 & 0,005 \\
\hline $\begin{array}{c}\text { Tidak } \\
\text { menggunak } \\
\text { an susu } \\
\text { formula }\end{array}$ & 30 & 57,69 & 22 & 44,47 & 52 & 100 & \\
\hline Total & 42 & 65,62 & 22 & 34,37 & 64 & 100
\end{tabular}

Berdasarkan hasil analisis dari 64 orang sampel, responden yang tidak menggunakan susu formula yang mengalami diare yaitu 0\%. Yang menggunakan susu formula yang mengalami diare yaitu 42,30\%. Hasil analisis didapatkan $\mathrm{p}$ value $=0,005$ lebih kecil dari $\alpha=$ 0,05 menunjukkan bahwa ada hubungan bermakna antara pemberian susu formula terhadap kejadian diare.

Secara global setiap tahunnya ada sekitar 2 miliar kasus diare dengan angka kematian 1.5 juta pertahun. Pada negara berkembang, anak-anak usia dibawah 3 tahun rata-rata mengalami 3 episode diare pertahun. Setiap episodenya diare akan menyebabkan kehilangan nutrisi yang dibutuhkan anak untuk tumbuh, sehingga diare merupakan penyebab utama malnutrisi pada anak (WHO, 2011).

Hal ini sejalan dengan penelitian dilakukan oleh irawan dan risky (2014) dengan judul Hubungan Pemberian Susu Formula Dengan Kejadiaan Diare Pada Bayi Usia 0 - 6 Bulan didapatkan hasil analisa hubungan pemberian susu formula dengan kejadian diare pada bayi usia 0-6 bulan di wilayah kerja Puskesmas Kenali Besar tahun 2013, diperoleh sebanyak 9 orang (7,3\%) ASI eksklusif mengalami diare dan 36 orang $(29,3 \%)$ susu formula yang mengalami diare. Setelah diuji secara statistik dengan Chi Square diperoleh nilai p-value 0,000 yang berarti $\mathrm{p}<0,05$ sehingga dapat disimpulkan bahwa H0 ditolak atau ada hubungan yang bermakna antara pemberian susu formula dengan kejadian diare pada bayi usia 0-6 bulan di wilayah kerja Puskesmas Kenali Besar tahun 2013. Dari hasil perhitungan $\mathrm{PR}=6.250$ (Confidence Interval $(\mathrm{CI})$ $95 \%=3.315-11.785$ ) dapat diartikan bahwa bayi yang diberikan susu formula memiliki risiko 6,250 kali terkena diare dari pada bayi yang diberikan ASI eksklusif.

Berdasarkan hasil penelitian dan teori yang ada, peneliti berpendapat bahwa ada hubungan antara pemberian susu formula dengan kejadian diare dimana bayi yang diberi susu formula lebih rentan terkena diare.

http://jurnalilmiah.stikescitradelima.ac.id/index.php/JI Vol.4,No.1, Juli 2020 
SIMPULAN

Ada hubungan bermakna antara pendidikan ibu dalam pemberian susu formula terhadap kejadian diare di Puskesmas "B” Kota Palembang Tahun 2019.

Ada hubungan bermakna antara pengetahuan ibu dalam pemberian susu formula terhadap kejadian diare di Puskesmas “B” Kota Palembang Tahun 2019.

Ada hubungan bermakna antara pemberian susu formula terhadap kejadian diare di Puskesmas "B" Kota Palembang Tahun 2019.

\section{DAFTAR PUSTAKA}

Dewiarti. 2013. Rellation Between The Levels of Parent's Education, Knowmledge, and Also Parent's Prevention Act to The Disease of Diarrhea Towards Cases of Toddlers. Diarrhea on Natar's Village Posyandu Natar Subdistrict South Lampung of Regency 2013. Lampung. Faculty of Medicine. Lampung University

Dwinda R, Octa, dkk, 2014. Buku Ajar Asuhan Kebidanan Neonatus, Bayi/Balita dan Anak Prasekolah. Yogyakarta : Deepublish

Fathia, H et al,.2015. Hubungan Tingkat Pendidikan dan Pengetahuan Ibu tentang Diare dengan Frekuensi Kejadian Diare Balita di Wilayah Kerja Puskesmas Tamansari.. http://ejournal.unisba.ac.id/ index.php/gmhc/article/view/1542.

Irawan and AR, Rizky (2014) Hubungan Pemberian Susu Formula Dengan Kejadiaan Diare Pada Bayi Usia 0 - 6 Bulan. Jambi Medical Journal, 2 (1). pp. 27-36. ISSN 2339-269x

Kalay. (2012). Hubungan Antara Tindakan Pemberian Susu Formula Dengan Kejadian Diare Pada Bayi Usia 0-6 Bulan di wilayah Kerja Puskesmas Ranotana Weru Kota Manado.

Kartika Sari Wijayaningsih. 2013. Standar Asuhan Keperawatan : Jakarta. TIM

Khasanah, Nur.2011. ASI atau Susu Formula. Jogjakarta: flashbooks

Mubarak, Wahit Iqbal. 2012. Promosi Kesehatan untuk Kebidanan. Jakarta: Salemba Medka

Ngastiyah. 2012. Perawatan Anak Sakit edisi 2. Jakarta: EGC
Notoatmodjo, S. 2012. Metodologi Penelitian Kesehatan. Jakarta : Rineka Cipta

Nursalam. 2011. Konsep dan Penerapan Metodelogi Penelitian Ilmu Keperawatan. Jakarta: Salemba Medika

Praptiani, Wuri. 2012. Kebidanan Oxford: Dari Bidan untuk Bidan. Jakarta: Buku Kedokteran EGC

Prihaningtyas. (2014). Deteksi dan Cepat Obati 30+ Penyakit yang Sering Menyerang Anak. Yogyakarta: Media Pressindo

Profil Kesehatan Indonesia (2016). Jakarta : Kementerian Kesehatan RI

Profil Kesehatan Indonesia (2017). Jakarta : Kementerian Kesehatan RI

Profil Kesehatan Indonesia (2018). Jakarta : Kementerian Kesehatan RI

Sodikin. 2012. Prinsip Perawatan Demam Pada Anak.Yogyakarta:Pustaka PelajarSuherna, C, Febry, F, Mutahar, R .2009. Hubungan Antara Pemberian Susu Formula dengan Kejadian Diare pada Anak Usia 0-24 Bulan di Wilayah Kerja Puskemas Balai Agung Sekayu. Universitas Sriwijaya, diakses 12 September 2019.

Sriwahyuni, M., Soedirham, O., 2014. Hubungan Faktor Lingkungan dan Perilaku Ibu dengan Penyakit Diare pada Balita di Surabaya. Jurnal Promkes Universitas Airlangga.

Suririnah. 2009. Buku Pintar Merawat Bayi Umur 0-12 Bulan. Jakarta: PT. Gramedia Pustaka Utama.

Sutomo, B \& Anggraini, D. Y. 2010. Makanan Sehat Pendamping ASI. Jakarta. Demedia.

http://jurnalilmiah.stikescitradelima.ac.id/index.php/JI Vol.4,No.1, Juli 2020 